\title{
Language, Translation and the Problem of International Accounting Communication.
}

\author{
Lisa Evans \\ School of Management, University of Edinburgh, \\ Edinburgh, UK
}

\begin{abstract}
Author's details:
Lisa Evans, School of Management, University of Edinburgh, William Robertson Building, 50 George Square, Edinburgh EH8 9JY, UK

Email: lisa.evans@ed.ac.uk Tel.: +441316503811 Fax.: + 441316508337
\end{abstract}

Financial assistance from the Scottish Chartered Accountants' Trust for Education (ICAS) and the Chartered Accountants' Fund for Education and Research (ICAEW) is gratefully acknowledged. The author is further grateful for helpful comments on earlier versions by Irvine Lapsley, Stephen Walker, Falconer Mitchell, Christopher Nobes, Bob Parker, Peter Walton, Axel Haller, David Alexander, Simon Archer, Heinz Giegerich, John Joseph, Kersten Honold, Brian Horne, participants of the EAA annual congress in Munich (March 2000) and by two anonymous referees. 


\section{Language, Translation and the Problem of International Accounting Communication.}

Keywords Accounting Terminology, Law, Translation, Principles of orderly Accounting, True and Fair View, Prudence

Abstract The use of technical terms to communicate accounting information can lead to misunderstandings when the meaning of such terms is not fully appreciated by the recipient of the information. The discipline of translation studies suggests that full equivalence in translation between languages is rare. This suggests that the risk of misunderstanding is exacerbated when technical terms are translated into another language. This article examines the implications of mistranslations of technical terms in the context of theories from linguistics which suggest that language influences the way we think. It uses three examples of accounting terminology to illustrate these problems. It concludes that the choice of an inappropriate label in the translation of accounting terminology is detrimental to international accounting communication and creates problems for users and preparers of translated financial statements as well as for researchers in, and students of, international accounting and for those involved in harmonisation and standardisation of accounting. 
Language, Translation and the Problem of International Accounting

\section{Communication}

\section{Introduction}

The purpose of this paper is to draw attention to the danger of misunderstandings inherent in the use of language as a means of communication in accounting. According to theories from the discipline of linguistics which suggest that language affects the way we think, this problem might be exacerbated by the translation of accounting or legal concepts from one language (the "source language") and cultural area into another (the "target language"). This problem has become more and more relevant through the increasing internationalisation of accounting and has implications for a number of different parties: It affects users (including investors, governments and stock exchange regulators) of financial statements which have been translated from one language to another, preparers of financial statements which are required to follow, or to be reconciled to, non-domestic accounting rules, researchers in and students of international accounting, and those involved in harmonisation and/or standardisation and policy making, and in the national implementation of international rules. It is also relevant because of the linkages between accounting and law. If international negotiators and national implementers wrongly believe that their understanding of an accounting or legal term is equivalent to the way it is understood in locations with different language and culture, and if the language and terminology used indeed affect the way we think, international harmonisation and/or standardisation of financial reporting will be severely hindered, as will be the appropriate application of rules in practice. If, due to poor translation, investors misunderstand elements of foreign language financial statements, misguided 
investment decisions may be taken. If researchers in international accounting do not fully understand the meaning of a foreign accounting term, their research may be seriously flawed.

One of the reasons for the misconceptions examined here is the difficulty of translating a foreign concept where an exact equivalent does not exist in the accounting terminology of the target language. According to Crystal (1987, p.15, with reference to the Sapir-Whorf hypothesis - see below), “... people certainly find it easier to make a conceptual distinction if it neatly corresponds to words available in their language". However, such a neat overlap of vocabulary is rare - which may lead to the use of the (perceived) nearest equivalent in translation. This, however, will lead to a blurring of meaning or loss of significant differences in the concepts. This paper draws on the Sapir-Whorf hypothesis from linguistics and on approaches from the relatively new discipline of translation studies. It argues that the language we use is linked to culture and affects our perception and thinking. Examples from accounting terminology are chosen to illustrate the difficulties that can arise. The paper concludes that the choice of a misleading label can create problems for different user groups of financial statements as well as for preparers, accounting academics, researchers and students of international accounting, and for those involved with harmonisation and international policy making. It can, in fact, add to the obstacles to successful international accounting harmonisation.

The remaining parts of this paper are structured as follows: The following section introduces the case studies from accounting terminology selected and provides an overview of the accounting and legal subcultures of which they are part. It further 
examines the historical and socio-economic contexts which gave rise to the different legal traditions and discusses how these latter affect accounting. The third section provides a brief overview of accounting literature drawing on the discipline of linguistics. This is followed by a discussion of other linguistics and translation studies literature which is specifically relevant to the focus of this paper on international accounting communication. Based on the literature reviewed, a proposition regarding the translation of technical terms is developed. In the fifth section, the case studies selected for the purposes of this paper are examined. The penultimate section draws on these case studies to re-examine the link between accounting, culture and language against the background of the paper's proposition. The final section concludes the discussion.

\section{Introduction to the case studies and the differences in legal and accounting}

\section{traditions}

The following examples are chosen from accounting terminology to illustrate the difficulties inherent in the use of inappropriate labels: the German term "Grundsätze ordnungsmäßiger Buchführung” (GoB; “principles of orderly accounting”); the English term "true and fair view" (TFV); and the terms "prudence" and "Vorsicht". These case studies are selected for the following reasons: They are examples of frequently used and fundamental accounting terminology, the equivalent interpretation of which would appear essential for international harmonisation; however, although they have to some extend been the subject of academic literature or publications by official organisations, their translations persistently give rise to problems and misunderstandings. They are also legal terms in that GoB relates to a requirement in the German Commercial Code, TFV features in the EU fourth 
directive and in the member states' laws, and "prudence" and "Vorsicht" appear, respectively, in the English and German language versions of the fourth directive and in UK and German company law. The discussion of the examples will focus mainly, but not exclusively, on the English and the German language, and the accounting and legal subcultures of Germany, the US and the UK. (The UK and US have similar, but not identical languages. It is argued below that especially the professional registers of these languages differ.) These languages and subcultures are selected because of the differing accounting and legal frameworks of the above countries, which are in turn due to cultural factors (in the widest sense, i.e. including socio-political, historical and economic factors). The focus on these countries is also interesting because they are countries with high degrees of economic development and with sophisticated accounting systems. Therefore any misunderstanding of important concepts of these systems could be very detrimental to international accounting harmonisation. The specific examples are selected because they illustrate the difficulties described: GoB is sometimes translated into English as (German) GAAP (generally accepted accounting principles/practices), leading to possible confusion especially with US GAAP; the TFV principle originates in the UK but was translated into the languages of all EU member states and beyond, however none of the translations appears to be equivalent to the English original; and "prudence" and "Vorsicht" were treated as equivalent in the EU's fourth directive, but applied and interpreted differently in the UK and Germany [1]. Many other examples could be discussed, however, given the qualitative approach employed here this would not be feasible within the constraints of an academic paper. For the same reason, the first ( $\mathrm{GoB})$ will be considered the main example and be discussed at greater length and in greater depth than the remaining two examples. 
Why do misunderstandings regarding GoB, prudence and TFV arise between members of the accounting and legal subcultures of Germany, the UK and the US, or in other words, how do these subcultures differ? Frequently cited causes for the differences in accounting systems include legal systems, economic circumstances, corporate financing, the size and power of the accounting profession, and (national) culture (see e.g. Gray, 1988; Belkaoui, 1990) [2]. Below, legal systems will be discussed in more detail. They are of particular relevance to this study because of their effect on the development, status and interpretation of accounting regulation and of the fact that the translation case studies examined here straddle the borderline between accounting and law.

The reasons for the structural differences in the families of laws are historical and cultural. Common law (CL) was first developed in England and still forms the most important part of English law. Other parts of English law are equity (see below) and, increasingly, statute. The origins of CL can be traced to the period following the Norman conquest (1066), but its formative period was the thirteenth century. No uniform body of law was available to be applied after the conquest. Initially AngloSaxon law remained in force and was administered locally, however, soon lost its ground. Socio-economic circumstances, in particular the fact that the Norman nobility did not understand the language or customs of the conquered country, meant that their own customs could not be easily applied to local conditions (Kiralfy, 1968; David and Brierley, 1985). The new circumstances led to the development of a unique type of feudalism with a more military and organised character than could be found in continental Europe, including "a strong and centralised administrative organisation" (David and Brierley, 1985, p. 311) with centralised royal power and courts (ibid., p. 
40). Comune ley or CL developed gradually, when the County courts were replaced by feudal courts, in particular the royal courts of justice (or Courts of Westminster), which, from the thirteenth century began to develop a CL applicable in all of England (David and Brierley, 1985, pp. 312-3). Thus judges made law, not however claiming juristic authority (Kiralfi, 1968, p. 163) but rather developing case law [3]. At first the royal courts' function was political rather than judicial, and they intervened merely in cases concerning royal finances, land ownership and serious criminal offences which affected the peace of the land (David and Brierley, 1985, pp. 313-4). They were initially not concerned with cases relating to the private interests of individuals, but gradually expanded their jurisdiction. By the end of the middle-ages they were effectively the only courts of justice and concerned mainly with private law disputes. For these historical reasons CL does not distinguish between private and public law (ibid., p. 321). According to Kiralfy a feature in common to all aspects of English law is a certain materialistic approach, intending to redress material loss but without much place for abstractions such as honour or prestige. Ethical ideas and a strong lay contribution where influential in its development, however Christian doctrines or economic theory had only limited impact (Kiralfy, 1968, p. 171).

CL is a positive system of law with formalist procedures and judicial traditionalism. The courts at Westminster followed strict fixed procedures regarding the steps to be followed, including the handling of evidence. Specific wording had to be used, the inappropriate use of which could damage the proceeding. English law had to develop within the framework of these procedures: "The CL did not appear to be so much a system attempting to bring justice as a conglomeration of procedures designed, in more and more cases, to achieve solutions to disputes" (David and Brierley, 1985, p. 
318). These features slowed and restricted its development and led, from the fourteenth and increasingly the fifteenth centuries, to the development of the rival system of Equity, based originally on natural justice and similar to and probably inspired by Roman law (Kiralfy, 1968). Equity allowed private persons who had not been able to obtain justice from the courts to appeal to the king on the basis of "the equity of the case". The decisions of the chancellor, made in the name of the king "became increasingly systematised and the application of "equitable" doctrines soon amounted to additions and correctives to the "legal" principles applied by the royal courts" (David and Brierley, 1985, p. 325), which resulted in both systems co-existing in a dual structure until today, whereby Equity corrects and complements CL. The "rules of Equity" have gradually lost their literal meaning and have developed into a second strict set of rules. (Nowadays remedial measures required to law are usually introduced by parliament, through legislation (David and Brierley, 1985, pp. 324-8).) The second half of the eighteenth century saw inter alia the integration of commercial law into CL, and the modern period the increasing development of legislation, general modernisation and legal reform, especially in procedure, and a systematic reorganisation of $\mathrm{CL}$ principles. The increasing social change gave rise to more importance being placed on statute, and EU law (based on Romano-Germanic law) has made an impact. In spite of this, and a degree of statutory consolidation, there was however "no codification along French lines and legal development remained, essentially, the work of the courts" (David and Brierley, 1985, p. 331). In spite of modernisations, the rigidity of the procedures ("from many points of view archaic and typically English", ibid., p. 323) left a continuing mark on the rules and categories of English law and prevented a more rational development of its institutions. This rigidity was also one of the reasons preventing the reception of Roman law in England 
and even required a process of "anglicisation" of borrowed elements from Roman or Canon law (ibid.). They also had an effect on the training and education of jurists (ibid., p. 323):

The complexity and technical nature of these procedures were such that they could only be learned through practice. ... In England, practitioners and judges, right up to the present time, have been trained essentially in the practice of law; for them, unlike their counterparts on the continent, university training has not been either necessary or, for many centuries even usual.

The system is pragmatic rather than abstract (Kiralfy, 1968, p. 159), with emphasis on the practical rather than the logical, little in terms of overall doctrines and theories, and "a distrust of philosophical analysis" (ibid.). It attempts to provide solutions to a trial rather than general rules of conduct (David and Brierley, 1985, p. 24). As a result legal topics and their subdivisions developed in tight compartments, with "sophisticated detailed rules to meet infinitely various situations but at a very low level of abstraction" (ibid., pp.166-7). In modern times, as the importance of statutes increased, the approach of courts towards them became increasingly literal. This was because the judges "feared the charge of usurpation of legislative power and at the same time resented the growth of statute law above their heads and gave it as little scope as possible" (Kiralfy, 1968, p. 170). Kiralfy refers to instances were courts "defeated the clear words of a statute" (ibid.), which forces those in charge of drafting new laws to adopt increasingly precise and narrow wording. As a result "a vicious circle resulted, the dry and unenlightening language of the statute giving ever less 
guidance as to its interpretation" (ibid.). David and Brierley stress that the historical development of CL has left its mark on at least four important aspects of modern English law. These are the remaining (although somewhat reduced) emphasis on procedure, the distinctive, completely different structure, including different categories and concepts of English law (such as CL and Equity), the lack of a distinction between public and private law and the fact that it created an obstacle to the reception of Roman law categories and concepts. In spite of increasing amounts of statute law, it remains uncodified.

German law is part of the family of Romano-Germanic (RG) legal systems. These systems are based on "revived" Roman law. The revival of Roman law studies, in particular the study of the works of Justinian, began in Italian universities, and soon elsewhere in continental Europe, from about 1100 (Wylie, 1948; Thomas, 1968), influencing the development of legal thinking and terminology. The spread of Roman law was helped by the ideology of a political and cultural "Rome-idea" (with little historical reality) which was utilised in the context of the German Holy Roman Empire's claim of a continuation from the original Roman empire. This idea appealed to the educated and ruling classes, and even where German political authority was rejected, a cultural "Rome-idea" manifested itself (Wylie, 1948). The spread of Roman law was also helped by the unifying international influence on European culture of Christianity, which had adopted many aspects of pre-Christian culture, including Roman legal writings, and strengthened the cultural "Rome-idea" through the Catholic church's links to Rome and the use of Latin as lingua franca (ibid.). Thus the development of RG law during the renaissance of twelfth and thirteenth century Europe was not linked to the creation of a centralised political power or sovereignity 
(as was that of CL in England), but rather to a common culture, independent of political considerations (David and Brierley, 1985, p. 40), which spread through new centres of culture and learning, in particular the new universities. These moved away from the law of Justinian and increasingly based their studies on reason, imitating the sciences, and attempting to develop law based on logic and able to serve as universal law for all people (David and Brierley, 1985, p. 46), a "scholarly law common to all Europe" (ibid., p. 40). This was not intended to be positive law, nor, given the local diversities in applied law and political administration, did it have the status necessary for this. It differed from the popular local laws applied by the courts, which “... in the eyes of the university, gave no expression to justice and was not law" (ibid., pp. 41-2). Thus Roman law, with strong emphasis on a concept of natural law, of a natural sense of justice, and as taught in the universities, provided a framework, vocabulary and methods to jurists intended to enable the search for just solutions (ibid., p. 45). These developments not only eventually led to codification, but also to a complete change of the nature of legal science: “... its philosophy changed the basis of the law, its resort to legislation and its development of logical propositions revolutionised its methods, and its influence on the substance of private and public law was considerable" (David and Brierley, 1985, p. 47).

Initially the evolving European law had merely persuasive authority in practice. It had to convince the people, the political leaders and the judges, if it was not to remain purely academic but also to be applied (David and Brierley, 1985, p. 49). In this it succeeded increasingly from the thirteenth century. More flexible, rational, sophisticated written, rather than oral, procedure led to "fundamental and decisive changes in judicial organisation" (ibid., p. 51). Increasingly, between the thirteenth 
and sixteenth centuries, justice became administered by jurists who had been taught in universities, and thus the law taught there became influential. Courts, "as guided by doctrinal writers" (ibid.) became responsible for developing law. This renewal of Roman law initiated the creation of the RG family of laws. It created the vocabulary, divisions, concepts, methods and approaches which were to be used by jurists (ibid., p. 52).

German private law is very closely based on Roman law. After the break-up of the Holy Roman Empire, centralised judicial organisation fell apart, and the German legal system could not develop on the basis of case law, thus opening the door for Roman law (David and Brierley, 1985, p. 58). This was, however not perceived as foreign (Wylie, 1948), partly because of the ideology of the political "Rome-idea" referred to above and the common culture referred to by David and Brierley (see above) [4]. Until the eighteenth century, legislation, as created by a sovereign, was of limited importance and remained mainly restricted to procedural matters, public law (administrative structures) and criminal law. However, in the eighteenth century the Natural Law School began to see in the sovereign a legislator with the power to reform law and to fully establish the authority of rules based on reason. According to David and Brierley, "[t]he Romanist legal system is relatively rational and logical because its substantive rules were organised by the universities and legislators". Codification helped to reorganise and systematise the law, to fuse theory and practice and eliminate archaisms. To succeed, however, codification needed certain preconditions which appeared to be present in France just after the Revolution, namely a sovereign willing to establish new principles of justice, freedom etc., and to 
take place in a country large and powerful enough to present a strong influence on others (David and Brierley, 1985, pp. 64-5).

Codification, however, led to the development of different national systems and reduced the role of the universities to glossing and carrying out exegesis of the texts. Thus "[c]ontrary to the very ideas which had inspired them, the codes engendered an attitude of legal positivism which was further aggravated by nationalistic sentiment" (David and Brierley, 1985. p. 66). The French Napoleonic Code was adopted in much of continental Europe, but only in some parts of Germany, and David and Brierley argue that this German rejection of French codification was (partly) at fault in destroying a European ius commune. The resulting time-lag between codification in France and Germany is one of the reasons for the main differences between French and German law. It allowed time for the development of a new German law school (the Pandectists), which continued the more active roles of the universities and "was successful in bringing the Romanist principles to a degree of systematisation hitherto unattained" (David and Brierley, 1985, p. 71), a historical accident which, while not creating a rift in the RG family, led to a difference in method and style between French and German Civil Codes (ibid.).

US law belongs to the CL family [5]. The structure of US law is in general analogous to that of English CL, with similar categories and an emphasis on judge-made law (in spite of increasing levels of legislation). However, certain structural differences exist, of which perhaps the most fundamental is the distinction between federal law and state law in the US. Other differences include classifications, concepts and terminology. Equity developed differently and constitutional and administrative law 
differ between the US and England. There are differences regarding the hierarchy of, and conflicts between laws, also between the individual federal states (David and Brierley, 1985, pp. 407-52). Differences can again be traced to historical socioeconomic and political circumstances. In the former British colonies, English CL applied. However, it was soon evident that its rules "were wholly inappropriate to the conditions and circumstances of colonial life", inter alia because of a lack of legal experts required to apply them (David and Brierly, 1985, p. 399). Further, this new society was different from the feudal one in which the rules had been developed and faced new types of problems. With American independence in 1783 the idea of an autonomous American law became popular. There was a certain enthusiasm for codification [6], partly due to the influence of the French and Spanish territories or settlers from non-CL countries, and a struggle ensued between the supporters of codification and those of CL. CL "triumphed" in the end, "a victory of tradition", aided by the English language as "the vehicle for the Common law throughout the country" (David and Brierley, 1985, p. 402). However, Roman law has left its mark on American CL, giving rise to some of its specific characteristics. Other differences between English and American CL arose because, after American independence, the laws developed separately, and because of environmental factors. Thus David and Brierley (1985, pp. 405-6) stress that geographic features, emphases on tradition, political systems, centralised versus federal administration, demographic features and education (including the education and training of lawyers) differ and give rise to differences between English and American CL.

$\mathrm{CL}$ and RG law have distinctive features of particular relevance to the problems examined here. In CL systems, general laws take precedence over specific ones, while 
this precedence is usually reversed in RG law systems. In the German system, "the thinking is abstract and system-oriented, while the method is deductive", while in Anglo-American systems "the method of legal thinking is inductive" (Smith, 1995, p. 191). Further, methods of legal interpretation differ depending on the legislation to be interpreted (Maley, 1994). In CL systems case law plays a more important role than in RG systems. With regard to legislation, the text, i.e. the wording of the statute, remains the most important source of interpretation, while in RG systems there is more scope for interpretation of the law by the courts, and it is possible to draw on the intention of the legislator. The implications for accounting are as follows: In general, countries with RG law accounting systems prefer accounting regulation to be subject to statutory control, rather than to control by the accounting profession. Thus regulation is to a larger extent enshrined in legislation and there is less scope for professional judgement. Also, importantly, specific rules usually take precedence over more general rules, such as TFV. (This will be discussed in more detail below.) That there is a clear link between legal systems and accounting systems has been established by Salter and Doupnik (1992, p. 20), who found that a dichotomisation of accounting systems is consistent with a CL versus RG law dichotomisation of legal systems. This is not surprising, given that the development of the main features of the legal systems of the countries under consideration preceded the development of accountancy in its modern sense. The latter could only fully develop when certain economic factors were in place, such as the increasing formation of companies and concentration of capital, which occurred inter alia as a result of the industrial revolution, especially from the second half of the nineteenth century. Because these factors were in place earlier, and also because of differences in the approaches to (legal) regulation, developments in the UK preceded those in Germany. 
In the UK, accountancy regulation has been traditionally developed by the profession, and is suited to an economic environment in which companies' equity finance is provided by "outsiders". It is associated with CL legal systems, typically shows a separation of the rules for financial reporting and for taxation, emphasises professional judgement, "fair" presentation and extensive disclosures (provided for the benefit of the external providers of finance). The main objective of financial reporting is seen to be the provision of useful information for economic decision making. In the UK an auditing profession developed earlier than in Germany, essentially because of the highly developed capital market and laissez-faire environment (see e.g. Matthews, Anderson and Edwards, 1998, pp. 242, 245), but also because of different corporate government arrangements: German companies were traditionally financed by debt capital provided mainly by banks, which had a close involvement with the companies, including representation on the companies' legally required "supervisory boards", a monitoring mechanism established to represent shareholders' and other stakeholders' interests vis-à-vis the management board (see e.g. Gietzman and Quick, 1998). Accounting is characterised by a close link between financial reporting and taxation, by emphasis on statutory control, conservatism, and secrecy. These features also have historical roots: In order to foster capital accumulation, in the late nineteenth and early twentieth centuries the German state positively encouraged conservatism and secrecy in accounting, also linking accounting and taxation (Gallhofer and Haslam, 1991). Regulation was more likely than in the UK to take the form of legislation or quasi-legislation and was, historically, strongly influenced by French legal writings. Hintner (1926, pp. 130-6) argues that the slower development of auditing in Germany was due to better protection provided to shareholders and creditors by law than was the case in the UK, 
i.e. a protection mechanism such as the audit was not at first considered necessary. One of the main objectives of financial reporting is still seen to be the protection of creditors, as the main capital providers, and of other stakeholder groups.

The US adopted many of the features of British professions and regulation, however, these developed to meet the specific local requirements. For example, there is little company law and no federal company law; and the Stock Exchange Commission (SEC), whose members are appointed by the President, has no equivalent in the UK. Accounting rules in the US, while created by a private sector body, are much more detailed than those in the UK, and the status of the requirement for "fair presentation" is more restricted than the UK's overriding TFV requirement (see below). Further, the response to the economic crises of the 1920s was in form of legislation (regulating share dealings, including the creation of the SEC) as was also the case in Germany (introducing inter alia the statutory audit requirement). Parallel to developments in law, in both countries business schools and universities also have played a greater and earlier role in the education of accountants than in the UK, and there has been a strong emphasis on theory, while in the UK there has been a more pragmatic tradition.

In summary, this section gave a brief introduction to the case studies, which will be discussed in more depth later in the paper. The main part of this section provided an discussion of how differences in the legal systems of the UK, Germany and the US evolved and how this relates to accounting. 


\section{Accounting and linguistics}

The study of accounting as a means of communication and providing information for the purposes of decision-making and accountability is increasingly drawing on the discipline of linguistics [7]. Early examples apply semantic differential techniques to measure and compare the meanings of accounting concepts as perceived by different groups of users or preparers of accounting information (Haried, 1972 and 1973; Oliver, 1974; Houghton, 1987). Perceptual differences of accounting concepts between different groups (academics, accountants and students) are also examined by Belkaoui (1980), using a socio-linguistic approach. Jain (1973) and Belkaoui (1978, 1989 and 1990, Chapter 3) treat accounting as a language or as analogous to language, based on the frequently used metaphor of accounting as the "language of business". Thus both Jain and Belkaoui apply linguistic theories about perception to accounting. For example, Belkaoui (1978, 1989 and 1990, Chapter 3) argues, on the basis of the Sapir-Whorf hypothesis (see below), that accounting as the language of business contains "lexical" and "grammatical" elements which shape the perceptions and behaviour of users. However, Parker (2000) argues that this metaphor is based on a misunderstanding of the nature of language. He argues

The metaphor is illuminating but also dangerous. Languages are not sets of rules imposed by regulation and which change only as the regulators so direct. Furthermore, of all languages, English ... is one of the least standardised and whose speakers have shown themselves unwilling to standardisation nationally, let alone internationally.

(Parker, 2000, p. 53, emphasis original) 
There is another concern regarding the metaphor: accounting rules cannot be considered independently of their expression through natural language. While accounting could perhaps be argued to have a "grammar" of its own in form of its techniques (Belkaoui, 1990, Chapter 3) or rules (Jain, 1973, p. 101), its lexicon, i.e. accounting terminology (Belkaoui, 1990, Chapter 3) is a professional register of a natural language. Language varies between different countries, even if the accounting rules do not (or vary to a lesser extent), for example, when IASs are translated into different languages, the "lexicon" changes, but not the "grammar". (At least that is the intention of the translators.) It is therefore doubtful whether the underlying assumption of the above studies, i.e. that accounting can be considered as analogous to a language, is entirely valid. By contrast, the approach used below considers the use of language in accounting rather than accounting as a language.

Belkaoui's (1990) complex model for an international theory of accounting considers the effects of cultural relativism, linguistic relativism, organisational culture relativism and contractual relativism. This is a very useful model, which suggests that the processes of forming judgements and making decisions are based on cognition, and that the cognitive processes are based on schemata which are determined by cultural, linguistic, organizational and contractual factors. However, these variables are not independent of each other, and their respective impacts are difficult, if not impossible, to isolate. This becomes evident for example in a study by Riahi-Belkaoui and Picur (1991), where the authors utilise a concept perception experiment in order to examine whether national culture determines a country's accounting techniques and perception of accounting concepts. They attempt to isolate the impact of national culture from those of organisational culture and linguistic relativism by choosing 
English-speaking subjects from the same large international accounting firm and from three offices in what they term "Anglophone" cities, i.e. Chicago, London and Torronto. They observe differences in the subjects' perceptions of accounting concepts which, they claim, partially support their cultural determinism hypothesis. However, their attempt to isolate the impact of culture from language is not entirely convincing, as different varieties of English are spoken in the three locations. This includes differences in the professional register of accountants (see for example Nobes, 2002b, pp. 179-80, or Parker, 2001, pp. 140-2). Nevertheless, Belkaoui's (1990) and Riahi-Belkaoui and Picur's (1991) theories are useful as long as a separation of the language and culture variables is not attempted. Bagranoff, Houghton and Hronsky (1994) attempt to measure connotative meaning across different cultures by examining the interpretations of the term "extraordinary items" by US and Australian accounting professionals. They find that "cross-cultural differences do give rise to differences in the cognitive structure within which meaning is held" (Bagranoff et al., 1994, p. 54). A more marginal use of linguistic theories is made by Walton (1991), in his examination of the TFV concept in British accounting, which draws on Saussure's distinction between "signifier" and "signified" (see below). Parker (1994) also draws on Saussure in an examination of the development of technical terms such as "accounting", "chartered accountants", and the components of the balance sheet.

Most of the above studies deal with issues of perception and communication on a single country or single language level. Problems are exacerbated when accounting practices and terminology are transferred or translated into another culture and language. However, translation has become a necessary feature of international 
accounting and law. The translation of selected accounting concepts is examined for example by Rutherford (1983), Parker (1989), Zeff (1990), Nobes (1993), Alexander (1993), Aisbitt and Nobes (2001) with regard to the TFV concept and by Evans and Nobes (1996) with regard to the prudence principle. Most of the above papers are descriptive in nature, not drawing on linguistic and related theories, while most of those that do draw on such theories are not concerned with translation. However, Archer and McLeay (1991) examine, against the background of theories from semantics and pragmatics, the linguistic implications of "transnational financial reporting" (ibid., p. 347, see below). Further, there is also a growing body of literature on the interpretation of "uncertainty expressions" (such as "probably", "likely" or "remote"). Davidson and Chrisman (1993) examine the interpretation of such expressions in IASs by Anglophone and Francophone Canadian students. The same authors also examine the interpretation of such expressions in Canadian auditing and accounting standards (Davidson and Chrisman, 1994). Both studies seem to suggest that the English terms allow a more precise interpretation than the French. Doupnik and Richter (2002a) compare the interpretation of uncertainty expressions in IASs by CPAs whose first language is American English with that of German, Swiss and Austrian "Wirtschaftsprüfer" (auditors) whose first language is German. They attribute the differences in interpretation they find to a language culture effect, which they consider to be independent of nationality. They also find that "for extreme probability expressions (highest and lowest), the translation from English to German results in significant differences in interpretation". They suggest that this may be due to poor translation or, alternatively, to a lack of an equivalent of the English term in German (Doupnik and Richter, 2002a, p. 16). (Based on translation theory, it is argued by this author that the existence of such equivalents would be rather 
exceptional.) A further study by Doupnik and Richter (2002b) looks at the interpretation of probability expressions in context, i.e. within extracts of IASs. They draw on Gray's (1988) work relating accounting to culture and conclude that "differences in cultural values can cause differences in interpretation of IAS probability expressions by German and U.S. accountants. ... Conversely, differences should not exist between accountants in two countries from the same cultural area" (Doupnik and Richter, 2002b, p. 18).

The contributions of this paper, compared to the previous ones, are that it examines the translation of accounting technical terms (rather than probability expressions), uses a qualitative approach and draws on translation theory. Further, the examples selected also relate specifically to the interface of accounting and law. Most prior papers looking at terminology specific to a professional register do not consider translation, but rather the interpretation of these terms by speakers of the same language (although possibly of different registers). The papers by Davidson and Chrisman (1993 and 1994) and Doupnik and Richter (2002a and 2002b), which do consider translation, employ statistical approaches. However, given the "fuzzyness" of language, culture, meaning and translation, a qualitative approach appears at least equally appropriate. This paper also looks at a very specific case relating to the translation of technical terms: the problems arising when the signifier chosen to translate a term is already associated with a specific meaning in the target language (see below). It appears to this author that this problem, which is related to the "Einstellung-effect" (see below), has not been considered sufficiently in the literature linking accounting and linguistics. 


\section{Language, culture and thought}

According to Saussure (1915), words in different languages are not equivalent. Not only the signifier (a sound pattern, a word), but also the signified (the underlying concept, whose meaning is determined by its position within the framework of all signifieds in the particular language) differ between languages (Joseph, 1998). The link between language, culture and thought is recognised inter alia in anthropology, philosophy, linguistics and translation theory. It was already expressed in the literary and philosophical discussions of the Romantic period (Joseph, 1998). The idea that language reflects and influences thought - in that speakers of different languages think in different ways - is reflected in the Sapir-Whorf hypothesis. This could be summarised by the following quote by Sapir (1929/1949, p.162, emphasis added):

Human beings do not live in the objective world alone nor alone in the world of social activity as ordinarily understood, but are very much at the mercy of the particular language which has become the medium of expression for their society. ... The "real world" is to a large extent unconsciously built up on the language habits of the group. No two languages are ever sufficiently similar to be considered as representatives of the same social reality. The worlds in which different societies live are distinct worlds, not merely the same world with different labels attached.

Werner (1994, p. 3656) explains this as follows: “... while nature is continuous, human beings cut nature into discrete categories and each culture does this cutting somewhat differently. People make up words or concepts in order to talk about their world or a cultural universe." There are different versions of the Sapir-Whorf 
hypothesis: a grammatical and a lexical version, and a strong and a weak version. The grammatical version sees cultural patterns relating to a language's grammar, while the lexical version looks for the interface between culture and language only in the lexicon (Werner, 1994). According to the strong version, thinking is determined by language (linguistic determinism) and according to the weak version, thinking is influenced by language (linguistic relativity [8]) (ibid.). While the weak version (usually in its lexical form) is generally accepted, the deterministic view of the strong version now receives little support (Crystal, 1987; Werner, 1994; Joseph, 1998 [9]; Thomas, 1998 [10]; see also Parker, 1994). Werner (1994, p. 3657) paraphrases the weak version as follows:

The categorial system of every language ... points its speakers toward somewhat different evaluations of externally similar observations. Hence speakers of different languages have somewhat different views of the world, somewhat different habitual thought, and consequently their language and cultural knowledge are in a somewhat different relationship to each other. ... The more dissimilar two languages are ... the greater is their tendency to embody different world views.

Györi (2000, p. 74) argues that "language functions as a device for cognition in as much as it provides a means to model the environment, and that this symbolic model can operate in various ways for deriving knowledge". He suggests that the semantic structure of a language affects the way we see the world because, as a cognitive device, it provides us with mental categories which in turn affect knowledge acquisition and remembering. These categories are relatively stable and, while they 
are essentially the result of the respective environment and culture, allow individuals to "culturally inherit" knowledge of previous generations without having to experience everything anew (ibid.). In summary, "[1]anguage may not determine the way we think, but it does influence the way we perceive and remember, and it affects the ease with which we perform mental tasks" (Crystal, 1987, p. 15). A related issue is the so-called "Einstellung" effect from psycho-linguistics, which is discussed (with regard to accounting as a language) by Jain (1973). This suggests that once a person has found a satisfactory verbal label for a situation, he/she will generalise this label and respond to it more than to the actual situation, i.e. the label leads the person to see only what he/she expects and "blinds" him/her to reality (Jain, 1973) [11]. Simple examples of the link between culture and language can be found in the fact that Eskimo languages have many words for snow, for which English has no equivalents (Crystal, 1987). Another example is Saussure's frequently quoted illustration of English "sheep" and French "mouton" (see also Joseph, 1998). Not only the signifier differs in English and French, but also the signified. (For example, the French includes both the animal and its meat, the English only the animal.) Other examples can be found in colour terminology and kinship terminology [12].

Translation theory (with or without direct reference to the Sapir Whorf hypothesis) recognises the fact that the link between language and culture makes translation difficult: "Since every language is ultimately sui generis - its categories being defined in terms of relations holding within the language itself - it is clear that formal correspondence is nearly always approximate" (Catford, 1965, p.27; see also Nida, 1996). In other words, absolute translation, absolute equivalence, are impossible (Bassnett, 1998). Some concepts are culture-specific to such an extent that there is no 
similar concept in other cultures. These concepts can include institutions, terms for behaviour, man-made objects, etc. [13]. The only way a translator can get close to conveying their meaning in another language is by explaining or describing them, using a number of words or phrases (circumlocution). The fact that such translation is however possible at all (if within limits), is quoted by Crystal (1987) as an argument against the strong version of the Sapir-Whorf hypothesis. Nevertheless, "working translators live with the constant guilt of knowing that they can never render the text faithfully in another language without doing violence either to the text or to the second language" (Joseph, 1998, p. 14). Even with simple, tangible concepts, meaning can almost never be transferred exactly from one language to another. Translation is only an approximation. Translation theory is, inter alia, concerned with exploring pragmatic solutions to this problem (see for example Joseph, 1998; or Hewson and Martin, 1991). The difficulties of translation of accounting terminology would of course not arise if there were such a thing as a transnational or translinguistic register of accounting. Such a possibility is investigated by Archer and McLeay (1991). A translinguistic register of accounting would mean that, internationally, accounting concepts would be similar enough to allow for equivalent translation. The authors stress the importance not only of semantic equivalence, but also of pragmatic appropriateness. Based on an examination of translated audit reports, they conclude that evidence in particular on the pragmatic level suggests that "at least in audit reporting the various national registers contain many idiosyncrasies which effectively militate against any translinguistic register" (Archer and McLeay, 1991, p. 360).

A body of literature applying linguistics-based theories, in particular also translation theory, to the translation of legal texts and terminology is relevant in the present 
context. A clash of legal traditions usually leads to a lack of equivalent terminology (Smith, 1995). For example, with regard to German and Anglo-American legal traditions "the root of the problems lies in their varying legal histories, cultures, and systems" (Smith, 1995, p. 179). David and Brierley (1985, p. 19) stress that each law constitutes a system, with vocabulary, concepts, categories and techniques of its own which are linked to the respective country's social order, which in turn determines how the law is applied. They (ibid.) suggest that:

With the possible exception of revolutionary upheavals, there are features of the law which can only be changed at the slow rhythm at which the civilisation of the country itself, the sense of justice of its citizens, its economic structure, language and social manners themselves are changed.

David and Brierley list a large number of French legal concepts which have no equivalent in English law and vice versa. While there may be overlap in their functions, there is no "identity" between the ideas and concepts. As a consequence, they warn against French-English or English-French dictionaries of legal terminology as "inevitably imperfect and often dangerously misleading when they attempt to explain the concept of one legal system by means of a concept employed in another" (ibid., p. 335). These translation difficulties are increased by the fact that legal language is a highly technical version (or register) of the respective standard language, with regard to lexicon and style (Joseph, 1995; Smith, 1995). The same applies to accounting language [14]. The differences in the approaches of the different legal traditions were discussed above. 
In summary, the above literature review suggests that (i) language and culture are closely linked; (ii) language influences perception and thinking (linguistic relativity); (iii) exact equivalence, or an exact transfer of meaning in translation, is (almost) always impossible; (iv) translation problems increase when different (legal or accounting) traditions clash. On the basis of the above discussion, and with reference to the weak version of the Sapir-Whorff hypothesis and the "Einstellung" effect, we can hypothesise that, if a concept or an idea is translated into another language, and the signifier used is already linked - in the minds of the native speakers of that language - with another concept or idea, it is likely that they will confuse the translation with the idea with which they are already familiar. To formulate a tentative proposition:

P: If a signified is translated using a signifier in the target language which is already associated with a particular signified in this (the target) language, then speakers of the target language will interpret it in association with the familiar signified.

\section{Three case studies}

The case of GoB

The main example to be examined against the background of the above proposition is the German term Grundsätze ordnungsmäßiger Buchführung (GoB: "principles of orderly accounting" [15]). GoB is sometimes translated into English as (German) GAAP. This translation is problematic. In the terms of the above proposition, it means that, if GoB is translated as GAAP, then English speakers will seize on aspects of their respective accounting culture (such as US GAAP) with which they are familiar and generalise this label in a way which may make it harder for them to grasp the 
meaning of the German concept. The differences between GoB and UK or US GAAP and the problems arising from mistranslation are addressed and critiqued by, for example, Macharzina (1981), Bloom and Naciri (1989), Lowe et al. (1991), Haller (1998), Alexander and Archer (1999); however, a large number of authors (including German authors) do use the term GAAP for GoB. However, this is a "wrong translation" (Macharzina, 1981, p. 131) and "a misunderstanding of German accounting" (Haller, 1998, p. 85), and evidence for a confusion of the different meanings of the terms.

Two possible meanings appear to crystallise from the use of the term GAAP in the accounting literature: first a general, broad meaning, where GAAP is used in its literal sense for accounting principles, rules or practices that are generally accepted at a particular time in a particular accounting (sub-)culture, independent of their source and their relationship to legislation or professional pronouncements; and second a narrow meaning which refers to GAAP in Anglo-American countries, in particular in the US. There the "House of GAAP" includes four categories of GAAP, from official pronouncements of the Financial Accounting Standards Board, which carry the strongest authority, to non-promulgated best practice, which carries the weakest authority (AICPA - American Institute of Certified Public Accountants - Statement on Auditing Standards 69). The latter plays a very minor role in comparison to promulgated GAAP. For example, GAAP is defined by Haskins, Ferris and Selling (1996, p. 863) as "[m]ethods identified by authoritative bodies (i.e., ASB, FASB, SEC) as being acceptable for use in the preparation of external accounting reports". 
GoB is an important concept in German accounting regulation and law. Some of its features appear similar to those of UK or US GAAP. However, it is argued here that a translation of GoB as GAAP would be inaccurate and misleading because, in spite of a certain superficial resemblance, GoB represents a fundamentally and conceptually different framework of rules. In spite of recent changes [16], German accounting is still predominantly based on commercial and tax law. This is likely to remain the case for unlisted and individual company accounts even after 2005, when EU listed companies will have to apply IASs in their consolidated accounts. While more accounting rules are laid down in German legislation than is the case for example for US or UK accounting rules, the law cannot cover all circumstances. GoB serves to fill gaps in the law and to aid its interpretation. According to the German Handelsgesetzbuch (HGB - commercial code) a business's books must be kept, and the annual accounts must be prepared in accordance with GoB (§ 239 (1) and $\S 243$ (1) respectively). Further, a corporation's financial statements must present "unter Beachtung der Grundsätze ordnungsmäßiger Buchführung ein den tatsächlichen Verhältnissen entsprechendes Bild der Vermögens-, Finanz- und Ertragslage” (approximately: "in accordance with principles of orderly accounting a picture of net assets, financing and results of operations, which corresponds to the facts") ( $§ 264$ (2)). The latter represents the German implementation of Article 2 (3) of the EU fourth directive, i.e. the TFV requirement.

Historically accounting rules in Germany were either legislation or GoB, but not both. However, the implementation of the fourth directive led to the codification of some elements of GoB. The term GoB is not defined, nor is its content detailed in the law. Its meaning and content have evolved over centuries through the influence of 
teachings, practice and administration of justice, depending on changes in the financial/economic environment, which increasingly relate to the internationalisation of business and of capital markets. These developments require corresponding changes to GoB. The GoB principles were originally inductively derived description of best practice, however since approximately the 1950s they developed a normative character (Schön, 1997, p. 145). There is now a wealth of literature on the deductive methods for deriving GoB. These methods draw on the intention of the legislator and the compromise required in considering the interests of all acknowledged stakeholder groups (see for example Coenenberg, 1994, pp. 26-7; Baetge, 1994, pp. 45-56; see also Beisse, 1993). Nevertheless, GoB based on court decisions appears to be the most authoritative (Leffson, 1987a). In practice, the evolution of GoB is influenced by individuals, including accountants, auditors and academics, and by institutions (Coenenberg, 1994, p. 26; Ordelheide and Pfaff, 1994; Haller, 1998; Ordelheide, 1999). In fact "the whole process of the informal development and improvement of GoB is a political process which is influenced by many differing and conflicting interests" (Haller, 1998, p. 86).

GoB forms a hierarchical system, which (in theory) is comprehensive, free of inherent contradiction, and flexible. However, in spite of many attempts to classify the principles of $\mathrm{GoB}$, this has not fully succeeded because of overlapping and interdependent elements (Coenenberg, 1994, p. 27). The most authoritative attempt was made by Leffson (1987b). A distinction can be made between "higher" and "lower" GoB (Leffson, 1987b; Beisse, 1990; see also Haller, 1998). The "higher" GoB have long been established and only questions of their relative weightings and borderlines are areas of theoretical studies (Beisse, 1990) [17]. They include inter alia 
principles that are similar (but not identical - see below with regard to prudence) to Anglo-American concepts such as accuracy, objectivity, clarity, completeness, the realisation principle, consistency and prudence [18] (Leffson, 1987b, p. 179; see also Baetge, 1994, pp. 58-72). From these "higher" principles the "lower" principles are derived, which address practical accounting treatments of specific items (Haller, 1998).

A mistranslation of GoB as GAAP or vice versa may be triggered because a number of apparently similar features between GoB and, for example US GAAP, may wrongly suggest that the signifieds are close enough to be considered equivalent for the purposes of translation, i.e. that they are part of a translinguistic register of accounting. Assuming that language, as a cognitive device, creates the mental categories required for knowledge acquisition and other mental tasks, such a mistranslation may result from, and perpetuate, the (wrong) assumption that GoB is the same or similar to US GAAP with regard to content, legal significance, objectives, users, sources, etc. In other words, because the signifier GAAP is associated with a specific meaning in the target language, this label will condition the mental processing of the information provided. Individuals may only take in what is already familiar to them, not what is different. However, that the similarities between GoB and US GAAP are very superficial becomes apparent on a more in-depth comparison. The key issues are as follows:

Accounting regulation in Germany encompasses much more than GoB, most notably the HGB. US GAAP, on the other hand, refers to different forms of regulation, though mostly promulgated. The scope and objectives of US GAAP accounts are much more 
limited than those based on the German HGB and GoB. The main or only objective of US GAAP accounts is the provision of information for investors, while German $\mathrm{HGB} / \mathrm{GoB}$ accounts have a number of functions, including to form the basis of taxation and of the calculation of distributable income (Schildbach, 2000, pp. 18-20). Further, US GAAP only applies to a limited number of large and listed companies, while the HGB and GoB apply to all business entities, irrespective of their size and legal form. Neither the precise meaning of the principles included in GoB, nor their application in practice or their weighting within the complete framework of rules are the same as those of similar principles in the US [19]. Further, German accounting regulation, including GoB, contains a much greater number of options than does US GAAP. GoB and GAAP also differ with regard to their sources: US GAAP is almost entirely created by private sector committees; the sources of GoB were discussed above. Finally, GoB has, in contrast to US GAAP, legal standing. Its elements are either legislation or unwritten case law ("richterliche Rechtsfindung") (Beisse, 1993), reflecting a stronger historical influence by the government and the courts on accounting regulation than was the case in the UK and US. This meant that there was no perceived need for a private sector standard setter to promulgate accounting rules in the sense of (US) GAAP. (For a more detailed discussion of the content of GoB see Working Group on External Financial Reporting of the Schmalenbach-GesellschaftDeutsche Gesellschaft für Betriebswirtschaft, 1995.)

In spite of these differences, there are many examples of the use of the term GAAP for GoB (and occasionally vice versa). These include authors writing both from a British and a German perspective, the latter writing in German or English. This suggests that the misunderstanding is mutual. The GoB/GAAP translation therefore 
provides evidence to support the above proposition. Examples of problematic translations of GoB as GAAP are given below:

The corporation's annual financial statements must present a factually accurate picture of the corporation's net assets, financing and results of operations according to generally accepted accounting principles.

(Peltzer, Doyle and Allen, 1995, § 264(2), bilingual translation of HGB)

In Germany, annual financial statements must, in accordance with generally accepted accounting principles, present a true and fair view of the net worth, financial position and results of the company.... Generally accepted accounting principles should be consulted to explain the legal requirements. They contain a set of rules which underlie all accounting principles. The most important of these principles is the principle of prudence. ....

(KPMG, 1994, p. 6; bilingual edition of guide to differences between UK and German accounting)

With due regard to the generally accepted accounting principles, the consolidated accounts give a true and fair view of the assets, liabilities, financial position and results of operations of the Bertelsmann Group. (Bertelsmann AG audit report, extract, November 1999)

The translation of GoB as GAAP is of particular concern in audit reports, where the resulting wording may resemble the audit report of US GAAP financial statements, 
thus possibly raising the expectation that the financial statements have been prepared in accordance with US GAAP (see also Zeff, 1990) [20]. Many uses of this translation can also be found in academic literature (see for example von Wysocki, 1983, p. 60; Busse von Colbe, 1984; Ordelheide, 1990, p. 8; Ordelheide, 1993, p. 84; Blake and Amat, 1993, p. 129). While it is likely that the majority of these academic authors are aware of the meaning of GoB (and sometimes move on to explain it), it is argued here that their chosen translation nevertheless acts to confuse. The reverse case, a translation of GAAP as GoB can also occasionally be found, for example (with reference to the UK context): "Does such a treatment correspond to the generally accepted accounting principles, i.e. the GoB, and above all, is it true and fair"? (Leffson, 1987a, p. 4, translation [21]), or:

Generally Accepted Accounting Principles - the $\rightarrow$ principles of orderly book-keeping and accounting issued in the individual Anglo-American countries usually by the local auditing or other accounting institutes ... and stock exchange supervisory bodies. Through the EG they are also gaining influence on accounting in the Federal Republic.

(Busse von Colbe, 1994, p. 235, translation [22])

Other examples of potentially problematic translations or uses of the term GAAP include statements which appear to equate (German) GAAP with legislation only, for example

Infineon Technologies $\mathrm{AG}$, as a German holding company, is subject to the German Commercial Code ("Handelsgesetzbuch", or "HGB”), which 
principally requires the Company to prepare consolidated financial statements in accordance with the HGB accounting principles and regulations (“German GAAP”).

(Infineon Technologies AG, Additional Information to the U.S. GAAP consolidated financial statement pursuant to HGB Section 292a [23])

Many other examples of such usage can be found in the accounts of large German multinational companies (see for example the website of Siemens AG, Annual press conference 14.12.2000 $\left[{ }^{24}\right)$, as well as examples of the use of the term (German) GAAP as synonymous with German accounting standards. This is problematic because there are very few German accounting standards, i.e. standards issued by the German Accounting Standards Committee, and these only apply to consolidated accounts. Readers may however not be aware that accounting standards play only a minor role within German accounting regulation. Another example of apparent misunderstanding is provided in the following quote from an international accounting textbook, where the term "(accounting) principles" is used ambiguously with reference to GoB.

German financial reporting is regulated by law and not by accounting principles. The provisions of the law are, however, in some cases supplemented by accounting principles. Section 149 of the 1965 German Stock Corporation Law, for instance, requires that financial statements be prepared according to the "principles of proper accounting".

(Evans, Taylor and Holzmann, 1994, p. 43) 
The problem here is the probability that the term "accounting principles" is understood by the authors' to be similar to US promulgated principles, i.e. standards. The suggestion that, on the one hand, German financial reporting is not regulated by accounting principles, but that on the other hand the law requires compliance with such principles, is confusing (as is the fact that the authors refer to an old version of the law, which was amended in 1985). The above examples provide evidence for the fact that GoB is sometimes translated as GAAP, and of similar problematic translations. Further evidence which this case provides in support of the above proposition will be considered in the penultimate part of this paper.

\section{The case of TFV}

A further example is the problematic translation of TFV. This concept originated in the UK, was exported to other Commonwealth countries and more recently, via the European Union's fourth company law directive, to all EU member states, and also to some of the transitional economies intending to join in the near future. However, as discussed above, continental European countries have RG legal systems, where more specific rules normally take precedence over more general rules. Thus in this case the clashes between legal systems and between their respective rules of legal interpretation are clearly detrimental to translation, in that the overriding TFV signified did not have an equivalent in continental Europe (except in The Netherlands - see e.g. Nobes, 1993; see also footnote 31). This was exacerbated by the greater emphasis on prudence in continental European accounting systems, the closer link between financial reporting and tax rules, and the traditional lack of pressure for "fair" reporting and disclosures. The translations of TFV have been discussed by Rutherford (1983), Zeff (1990), Nobes (1993), Alexander (1993), Aisbitt and Nobes 
(2001) and Kosmala MacLullich (2001). Not only do none of the signifiers used in the target languages appear to be literal translations of "true and fair", but it is clear that the signifieds and the practical applications of the concept also vary (Nobes, 1993). For example Parker makes the following observation:

\begin{abstract}
Whilst it is at first sight surprising that the Continental European countries have accepted such a concept it is clear that what they have really imported is a form of words which they are translating and applying so as not to disturb unduly what already exists. Perhaps this is the fate of all indefinable concepts.
\end{abstract}

(Parker, 1989, pp. 23-4)

David and Brierley (1985, pp. 334-5) argue that "English legal terms cannot be translated simply and effectively into French or some other Latin language. If a translation must be made, whatever the price, the meaning is most often completely distorted". They can equally not be translated into German. With regard to TFV it is especially important to stress the differences in the drafting of legal rules: in RG systems, rules have a more general character, are less precisely formulated than in CL countries and allow more discretion for interpretation through the judge (ibid., p. 98; see also above). This leads Grossfeld (1989, p. 871) to suggest that the overriding TFV requirement in the fourth directive relates specifically to English legal drafting techniques, but adds little to RG interpretation.

The proposition suggested in this paper is perhaps best supported by Zeff's (1990) paper, which discusses the translations of the Dutch concept "geeft een getrouw 
beeld". This tended to be translated by auditors as "present fairly" or as "true and fair view". Zeff argues that the translation as "present fairly", which is based on the wording in the US American auditor's report, is inappropriate, and that the Dutch phrase should be translated as "true and fair view". This is because the US "present fairly", although superficially similar, is always subject to "conformity with GAAP" and in practice is unlikely to lead to the override of promulgated GAAP (Zeff, 1990; see also Van Hulle, 1997). Thus the choice of the signifier used to translate "geeft een getrouw beeld" into English could result in two different interpretations - one in line with EU law (based on the original UK term), the other in line with US regulation. Further evidence is provided by an examination of the signifiers used to translate TFV into other languages. As suggested by Parker (above), the signifiers often reflect what already exists. For example, the translation into Finnish appears to emphasise "correctness", as does the version adopted in Italian legislation, while the Spanish law adds the phrase "de conformidad con las disposiciones legales" ("in conformity with legal provisions"). A similar "qualifier" is added in German, with regard to "in accordance with GoB" (see above). Kosmala MacLullich (2001) finds that a number of different signifiers have been used to translate TFV into Polish. Many appear to emphasise "correctness". Kosmala MacLullich argues that the diversity of translations and a general lack of agreement on the role of TFV in Polish accounting reflect the incompatibility of the messages conveyed by TFV in English and in the Polish translations. In this author's opinion, the different emphases in the translations of TFV are in keeping not only with the different legal traditions of RG law versus CL, but also with the differences in the accounting subcultures discussed above. For example, an emphasis on the protection of creditors, less pressure for the provision of information to outsiders, a close link between accounting and taxation, as well as a 
tradition which places more emphasis on statutory control than on professional judgement, all conspire against an interpretation of TFV equivalent to that in UK accounting culture.

The case of "prudence" and "Vorsicht"

Another example is provided by the terms "prudence" and "Vorsicht". These are terms used in everyday language, which take on a more specific meaning in the professional register of the accounting subculture. But even in their everyday use, the terms are not exactly equivalent [25]. The concept of prudence is probably know in most accounting systems, but is emphasised to very different degrees. Prudence is one of the accounting principles explicitly required in the preparation of financial statements by the EU's fourth directive. Like all directives, the fourth directive was translated into the official languages of all member states prior to implementation in the member states' national laws. However, according to a 1995 EU Commission document (Accounting Advisory Forum, 1995) it soon became apparent that, based on the same text (but note: in different language versions) member states differed in the interpretation and application of accounting principles, most notably with regard to prudence, which affected in particular differences in the realisation of profits. The EU document acknowledges that these differences are likely to be due to the fact that the application of prudence requires the use of judgement. Judgement is related to perceptions of uncertainty and risk, which differ. According to the EU document, differences in the emphasis on prudence may be due to differences in history and traditions, culture and language, and different legal and economic environments, and perhaps most significantly due to differences in the perceived objectives of financial statements; further the influence of taxation and/or statutory requirements regarding 
dividend distribution are important factors. Such differences lead to prudence being interpreted by some as one among a number of qualitative characteristics of financial statements which enhance the usefulness of these statements, and as "an attitude of mind, denoting the careful assessment of all uncertainties and a vigilance to possible risks", but not to be seen as overriding other accounting principles or giving rise to systematic measuring bias (Accounting Advisory Forum, 1995, paragraph 9).

However, in some countries prudence is considered the most important, overriding principle of the fourth directive (ibid.). Thus accounting in continental European countries tends to be more conservative than that in Anglo-American countries; e.g. German accounting is more conservative than that in the UK (Gray, 1980; Evans and Nobes, 1996) [26]. In fact, in Germany "Vorsicht" has traditionally been considered the most important accounting principle (see e.g. Ordelheide, 1993). Further, the German concept of "Vorsicht" is related to another concept, the so-called "Imparitätsprinzip" (principle of imparity). This demands that gains have to be treated differently from losses, i.e. requiring an imbalance and bias towards prudence very much in conflict with the realisation principle. Examples of the stronger emphasis are the more generous use of provisions, stricter application of the historical cost principle, the use of LIFO in inventory valuations at times of rising prices, or the use of the completed contract method for long-term contracts. The reasons for this emphasis are historical and relate to the late nineteenth/early twentieth centuries' German governments' desire to prevent excessive distributions of capital and to link accounting with taxation (Gallhofer and Haslam, 1991), and to the emphasis on the protection of creditors as the (historically) main providers of finance for companies. 
The more conservative approach of German accounting may also be the consequence of certain features of German national culture (see Gray, 1988; but see footnote 2).

Doupnik and Richter (2002b) also present evidence for a more conservative approach of German (as opposed to US) accountants, and, important in the context of this paper, evidence that this is reflected in their use of language. The authors link differences in conservatism to differences in interpretation of "in-context" probability expressions in IASs. Further, Garcia Lara and Mora (2002) establish a link between prudence and legal systems by showing that balance sheet conservatism is higher in European RG law countries, while earnings conservatism appears to be higher in the UK, as a CL country. (However, this latter finding was statistically only significant in comparison with Germany.) They argue that the higher balance sheet conservatism is due to accounting regulation, which in continental European countries was developed to protect creditors. The higher earnings conservatism in the UK is attributed to higher litigation risk (rather than regulation).

Evans and Nobes (1996) comment on the difference between the terms "conservatism" and "prudence". They point out that both terms were used in English language documents around the time of the negotiations surrounding the fourth directive, but that there appeared to be little systematic difference between them, "except that "prudence" might be used to avoid the connotations of secret reserves and other practices once associated with the older word "conservatism"" (Evans and Nobes, 1996, p. 363). "Conservatism" also seems to be the preferred term in US usage. More significantly, Evans and Nobes note that English is the only language version of the fourth directive which does not emphasise prudence beyond the other 
accounting principles of the directive, when it states that "The principle of prudence must be observed in any event" or “... in every case” (Evans and Nobes, 1996, p. 362) [27]. The authors suggest that there was a shift away from a stronger emphasis on prudence in the US and the UK since the 1960s/70s [28] and that the lack of emphasis in the fourth directive, if it was not a linguistic "accident", could have been due to a "wording arranged by the Council secretariat in order to make the drafting more acceptable by the UK" (but which was not publicly discussed). It is interesting to note that, for whatever reasons, the differing emphases on prudence typical for the differing accounting systems were reflected in the different language versions of the fourth directive. It is at least possible that this difference reinforced the different interpretations of prudence noted by the Accounting Advisory Forum. However, the main argument of this paper, in line with the suggested proposition, is that the terms "prudence" and "Vorsicht" mean somewhat different things to UK and German accountants respectively, and that these differences were not overcome by the harmonisation effects of the fourth directive, because the English and German language versions used signifiers predating the directive, which, because they relate to different "mental categories", predisposed readers to interpret the directive's rules in line with their familiar "reality" or subculture. This suggestion is supported by the literature reviewed, and in particular by the findings of the Accounting Advisory Forum.

\section{The link between accounting, culture and language}

At the end of the third section of this paper, the following had emerged from the review of previous literature: (i) language and culture are closely linked; (ii) language influences perception and thinking (linguistic relativity); (iii) exact equivalence, or an 
exact transfer of meaning in translation, is (almost) always impossible; (iv) translation problems increase when different (legal or accounting) traditions clash. It was suggested that, if a term is translated into another language, and the signifier used in the target language is already linked - in the minds of the native speakers of that language - with another concept, it is likely that they will confuse the translation with the idea with which they are already familiar. This suggestion is supported by linguistics and translation theory literature, in particular by the notion that language is a cognitive device which provides us with the mental categories in which we think and learn. These mental categories differ in different languages and cultures, which suggests that exact equivalence in translation does not usually exist. Language and culture are closely related and there appear to be mutual influences. For example, Györi (2000, p. 74) states that “... the different environments (social, cultural, historical, etc.) in which different languages are used will exert their effect on the various languages"; but also that "different languages impose different categorizations on the world" (ibid.). Not only national cultures and languages, but also accounting and legal subcultures and professional registers differ. There is, to this author's knowledge, no evidence for the existence of a transnational register for accounting. This suggests that the translation of accounting concepts would be difficult. According to Doupnik and Richter (2002a, p. 4):

a country's authoritative literature can define a specific accounting concept in such a way that it differs from a similar (but not identical) concept in another country. Accountants "learn" accounting concepts within the context of the accounting framework and traditions specific to an individual country. 
Due to the differences in legal systems and interpretations discussed above, the problem is exacerbated where concepts span the accounting and legal subcultures. In particular, given the proposition developed in this paper, the existence of similar but not equivalent signifieds creates problems when existing signifiers are used in translation. The three examples provided above illustrate that GoB means something quite different from GAAP, that "Vorsicht" in Germany carries different, and probably stronger connotations than "prudence" in the UK and that translations of TFV do not appear to correspond to the original UK concept. The examples have provided evidence that the accounting terms examined are part of a unique environment, including legal environment, and that the signifiers used in translation are not equivalents. They have further to some extent provided evidence of potential and actual misunderstandings. Further evidence to support this paper's proposition that problematic translations do in fact lead to misunderstandings is available in the academic and professional literature regarding the implementation of the fourth directive's TFV requirement in Germany, where inter alia the relationship between the three examples investigated here was discussed. Attempts to define TFV and establish its relevance for German accounting frequently led German academics to consider the UK context. This itself often led to confusion regarding the role of UK GAAP and of GoB. The confusion was due to a (wrongly) perceived similarity between those two frameworks, which had the effect that the German academic literature of the time contains many examples of authors translating GoB as GAAP.

This often created additional misunderstandings, also with regard to TFV. For example, Niehus (1979, pp. 224-5), after reviewing UK, Australian and New Zealand literature, comes to the conclusion that TFV, GAAP and GoB mean essentially the 
same thing and that "further we consider the assumption to be valid that it would no longer be referred to as "true and fair view", but for example "generally accepted accounting principles", if these had also already been developed in Great Britain" (Niehus, 1979, p. 225, translation [29]). The same conclusion is drawn by Scholtissek (1984 and 1986), a practitioner. Scholtissek argues that, according to the "leading British opinion", TFV means preparation of financial statements in accordance with generally accepted accounting principles. Later he translates GAAP as GoB: "The norm true and fair view means thus in conformity with the Grundsätze ordnungsmäßiger Buchführung”. He concludes that for the implementation in Germany, "[t]he reference to GoB in $\S 237$ para. 2 HGBE means no restriction, but is a tautology" (ibid., p. 68, translation [30]). However, in the UK the relationship between GAAP, accounting standards and TFV is a moot point. While is has been argued by some that TFV is or should be explicated with reference to GAAP, others have objected. Further, (unlike in the US) it is not defined what is meant by GAAP in the UK, nor does this term have legal significance (for different views or reviews of literature see for example Rutherford, 1985; Walton, 1991; Arden, 1993; Alexander, 1993 and 1999; see also Zeff, 1990, above). In summary, GoB has different sources, a different content, hierarchy and weighting of concepts, and different legal significance than both UK GAAP or US GAAP. While the term German GAAP is used by some writers to refer to the German accounting framework including legislation and GoB, and may thus be legitimate, others use it to refer only to some aspects, i.e. GoB. Even if used correctly, it may still lead to misunderstandings by the recipients of the message. This is because they already have a "mental category" for GAAP, which is usually linked to accounting regulation in Anglo-American countries. The use of this 
label may therefore hinder them to fully understand the very different accounting regulatory frameworks in Germany.

The signifiers "prudence" and "Vorsicht" were used as equivalent in EU directives and other official documentation. However, "prudence" and "Vorsicht" do not mean the same thing; their signifieds differ somewhat in the UK and German accounting and legal subcultures. This is supported by the Accounting Advisory Forum (1995) document, by the brief discussion of literature on prudence above and by the earlier discussion of accounting subcultures. Thus if a German accountant encounters the word "Vorsicht" in EU documentation, he or she will interpret it differently (based on the German accounting subculture) from the way a UK accountant might interpret the word “prudence". For example, Ordelheide (1993, p. 83), from a German perspective, claims that the realisation principle of the directive is "a sub-principle of the prudence principle" and that the European TFV principle requires an essentially prudent approach to accounting. Therefore the UK's percentage-of-completion method of SSAP 9 and the treatment of foreign currency translation of SSAP 20 are in breach of this principle. However, it is arguable whether Ordelheide's implicit claim that the directive emphasises the prudence principle beyond the other principles is supported by the directive itself. Alexander (1996) points out that prudence is only one of the principles required by the directive to be applied in the context of valuation, and that there is no justification for specifically emphasising prudence. Both authors refer to the text of the directive. There are two possible reasons for the differences in their interpretation: (i) the lack of emphasis on prudence in the English language version, which appears symptomatic of the different accounting subcultures (see above), and 
(ii) the different signifieds underlying the signifiers "prudence" and "Vorsicht" in the UK and in Germany.

While the examples of GoB/GAAP and "Vorsicht"/"prudence" illustrate problems arising from translation where a similar (but not equivalent) concept already exists in the target language, TFV is slightly different, in that it does not appear to be similar to any previously existing concepts in most continental European accounting systems [31]. Thus many of the translations adopted in continental European countries refer to ideas more familiar and in keeping with the respective accounting subculture, for example an emphasis on correctness. This suggests that it is easier to equate the unfamiliar with the familiar than to attempt the creation of new mental categories (but not impossible - see below). The following quote provides a further example:

At a seminar held in England in 1973 for UK and German accountants, the participants spent considerable time in discussing the term "true and fair view" and concluded that the term should be interpreted to mean "fairly true and fairly fair".... It is interesting that this should have come out of an Anglo-German seminar because this interpretation of "true and fair" closely resembles the German requirement in $\S 149$ of the Aktiengesetz (the public Corporation law 1965) that the financial statements should give "a sure as possible [sic] insight into the financial position and results of operations".

(Chastney, 1975, pp. 46-7) 
However, that is not the case. For example, the old German "general clause" required unambiguously that GoB had to be followed; it was subsidiary to the application of detailed legal rules (Schildbach, 1979); required less information content of the financial statements (Ballwieser, 1985); and, apparently, was in practice often ignored (Leffson, 1979).

How can translation difficulties such as the ones discussed above be overcome? Different approaches are suggested for dealing with the lack of equivalents: Archer and McLeay (1991), with regard to audit reports in translated financial statements, examine various types of "avoidance strategy", which means all or part of a message in the source language is simply omitted in the target language. Other strategies include coinage of a new term in the target language, circumlocution (ibid.), i.e. the introduction into the text of short explanatory phrases or commentaries (see also Smith, 1995 and Joseph, 1995), approximation or paraphrasing (Archer and McLeay, 1991). An additional approach is referred to as non-translation (Smith, 1995), interlanguage transfer or language switching (Archer and McLeay, 1991). However, Smith argues that this creates an elitist language inaccessible to the uninitiated, and, perhaps more importantly, "it also bears the risk of miscommunication if isolated terms are taken out of context" (Smith, 1995, p.188). It appears to be a feature of the evolution of languages that at times they are "elaborated" with terms from other languages which are considered "prestigious" (Joseph, 1995, with reference to legal English). This might suggest that German accounting academics using Anglo-American terms instead of the established German ones are looking towards Anglo-American accounting for guidance. To this author, two issues appear important: to convey, as much as possible, the content of the "foreign" term (and where relevant, its legal 
status) and to avoid the use of an existing signifier in the target language if such use could lead to confusion with an existing signified. Thus "principles of orderly accounting", while perhaps not a perfect translation of GoB, at least signals that it is something other than US or UK GAAP.

\section{Some concluding remarks}

The issues discussed earlier in this paper suggest that language, culture and thought are linked, that language and culture mutually influence each other and that a language predisposes its speakers to particular ways of thinking and of perception. This suggests that speakers of different languages also perceive and interpret accounting concepts in different ways. Thus important differences between concepts may be lost through mistranslation. The above examples support the suggestion that poor translation can lead to difficulties in international accounting communication. The use of a particular label is especially misleading where it is already associated with a specific meaning in the target language which does not correspond to the signified in the source language. The examples also illustrate that misunderstandings do in fact arise. This can be especially serious where it involves making investment decision based on translated financial statements, where elements of translated audit reports may be misunderstood (see Zeff, 1990), where it may bias a research project (see Lowe et al., 1991, above), or where it may adversely affect accounting harmonisation and policy making.

In summary, the problems discussed in this paper occur because different languages and/or professional registers influence the cognitive processes of the members of their respective cultures or subcultures. With regard to accounting "different cultural 
groups in accounting create different cognitions or systems of knowledge for intracultural communications and/or intercultural communications. These, in turn, lead to different understanding of accounting relationships" (Riahi-Belkaoui and Picur, 1991, p. 119). Further research regarding the translation of accounting terms into other languages is urgently required, especially in the context of the politics of international accounting harmonisation and standardisation. A fuller explanation or description of concepts in the different cultures from the perspectives of their respective frameworks and practical applications is also required (with regard to such approaches see for example Lowe et al. (1991)). Further, the literature examining different professional registers within the same language (such as those of lawyers and accountants) would benefit from additional contributions.

Finally, this paper does not suggest that communication across cultures is impossible. Linguistic relativity does not imply that translation is not possible at all, or that the categorisations imposed on us by our languages are unalterable and inflexible (Györi, 2000, p. 76). The clash of different cultures makes it harder, but it may also make it richer (Popper, 1994; Thomas, 1998; Joseph, 1998). Translation is not impossible but we have to accept that it is likely to be incomplete. Special care therefore has to be taken especially where similar, but not equivalent words and concepts already exist, and in particular where this occurs in the domains of law and accounting regulation. 


\section{Notes}

1. Another reason for the focus on examples from English and German is the fact that the author is bilingual in these languages.

2. However, for example Nobes (2002a) and d'Arcy (2001) find that the impact of national culture on accounting systems is too indeterminate to be of much benefit to researchers. Different authors use different definitions for culture, or, as common in the translation theory literature, provide no definition. Much of the critique regarding proposed linkages between accounting and culture can be related to the definitions of culture proposed in accounting literature or attempts to measure its component parts (see e.g. Baskerville, 2003). On the other hand, "when anthropologists adopt any such concepts of culture, culture is not devided into component systems, or different values in a quantitative style; instead it is viewed as an integrated pattern of symbols and meanings" (ibid., p. 2). Where "culture" is referred to in this paper, it is used in its widest sense, including its socio-economic, political and institutional manifestations.

3. The case law decisions were presented as based on "reason", but essentially expressed perceptions of justice and political expediency of their time, and were based partly on local customs and even on some elements of Roman law (David and Brierley, 1985, pp. 322-3). They were later claimed to be based on "general immemorial custom", however this was a fiction invented to provide CL with a foundation in line with Roman and Canon law theories (ibid.).

4. The efforts of a number of eighteenth century authors to "de-Romanise" German law and to create a systematic German law came too late (David and Brierley, 1985, p. 59).

5. Although the federal state of Louisiana has, due to its historical heritage, a mixed CL/Roman-law system.

6. As for example evident in the Constitution.

7. There is also a large body of literature examining the interface between language and law. Some of this will be discussed below.

8. Note that this terminology ("linguistic determinism", "linguistic relativity", "cultural relativity", etc). is not always used consistently in the literature.

9. Joseph is particularly critical of a deterministic view of language, especially where this leads to claims that translation is impossible. But see also Joseph (1995) on the difficulties of legal translation. 
10. Thomas (1998) reviews literature accepting and rejecting the hypothesis. Based on Lucy (1992), Wierzbicka (1992) and Sampson (1997), he accepts the weak version of the hypothesis.

11. See also Belkaoui (1990, Chapter 1) with regard to schemata in the context of cognitive relativism.

12. For example, with regard to colour terminology, colour recognition and memory appear linked to a language's lexicon (see for example Lucy and Shweder (1979) (in Werner, 1994). Figure 1 illustrates the fact that colour terminology in French and Welsh is not exactly equivalent. [Take in Figure 1.]

13. Albrecht (1973) gives inter alia the following examples: "Kreisstadt", "vin d'honneur", "Schadenfreude", "Pumpernickel”, "ratatouille". Kelly (1994) gives examples from Latin ("consul", "praetor", "aedile", "quaestor") and points out that the difference between French "fleuve" and "rivière" is lost in English, further that certain physical features (such as "snow" or "ice" may be untranslatable in some (tropical) languages. Catford (1965) suggests as examples "sauna" or "yukata" (a Japanese item of clothing). Smith (1995) gives a number of examples from legal translation, including the English "in the best interest of the child" and "punitive damages", which have no equivalents in German.

14. Another difficulty arises (as in the case of TFV) when the same terminology is interpreted differently by accountants and lawyers (see for example McGee, 1992).

15. Alexander and Archer (1999) list six different translations for GoB found in the literature. These are: "required accounting principles" (Ordelheide, 1990, p. 8; Nobes and Parker, 1995, p. 26), “generally accepted accounting principles" (Ordelheide, 1993, p. 84), "principles of regular accounting" (Ordelheide and Pfaff, 1994, p. 104), "principles of regular book-keeping" (Ordelheide and Pfaff, 1994, p. 93), "principles of proper accounting" (FEE, 1997, p. 69), "principles of orderly book-keeping" (Alexander and Archer, 1999). Additional examples can easily be found by a review of textbooks on international accounting.

16. These changes include inter alia the creation of a private sector standard setter (with, however, a rather limited remit), moves to relax the link between financial reporting and taxation, and a change to company law which permits corporations to prepare consolidated accounts in accordance with US GAAP or IASs.

17. Thus the elements tend to be the same but their classifications differ; for example Beisse (1990) distinguishes between "formaler" (presentation) and "materialer" (measurement) GoB. Busse von Colbe (1994, p. 283) distinguishes between principles of presentation and accountability (which overlaps with Beisse's classification). Other classifications may include some GoB apparently missing from the above 
list, such as relevance and going concern. However, such omissions may be more apparent rather than real, merely due to the choice of "label", especially as this is complicated by translation. Ordelheide and Pfaff (1994, writing in English) also include security (including, inter alia, timeliness), verifiability, auditability and economy.

18. CAVEAT. Of course this paper presents a dilemma and a number of possible traps for the author: As much of the literature reviewed is in German, it will be necessary from time to time to translate German terms into English. As equivalent terms are rarely available, it would be much preferable to explain or describe the functions of the German terms and their place within the frameworks of which they form part - however, this would be beyond the scope of an academic paper.

19. For these reasons, and because of its different development and sources, GoB does not form a conceptual framework in the understanding of Anglo-American conceptual frameworks in spite of the fact that the principles that make up the "higher GoB" appear similar to the quantitative characteristics of conceptual frameworks (Haller, 1998, pp. 86-91). Further, while GoB forms a legal requirement in Germany, the same does not apply to the FASB's conceptual framework in the US. In fact, the conceptual framework does not form part of US GAAP. Thus GoB and Anglo-American conceptual frameworks differ with regard to their legal significance, their content, and, perhaps most significantly, with regard to the users and objectives of financial statements.

20. This is less likely to occur in future because of an initiative by the International Forum for Accountancy Development, which recommends that auditors' reports should identify the applicable national framework for the preparation of the financial statements audited.

21. "Entspricht ein solcher Ausweis den general accepted accounting principles, also den GoB, vor allem aber: ist er true and fair?"

22. "Generally Accepted Accounting Principles - Die in den einzelnen anglo-amerikanischen Ländern meist von den dortigen Wirtschaftsprüfer- oder anderen Rechnungslegungsinstituten ... und Börsenaufsichtsbehörden erlassenen $\rightarrow$ Grundsätze ordnungsmäßiger Buchführung und Bilanzierung. Über die EG gewinnen sie auch Einfluß auf die Bilanzierung in der Bundesrepublik."

23. http://www.infineon.com/boerse/download/IFX\%202000_AdditionalInformationtotheUSGAAP consolidatedfinancialstat.pdf

24. Siemens AG: http://w4.siemens.de/en2/html/press/pk/neubuerger_rede.pdf 
25. The literal translation of the German term "Vorsicht" into English would be "caution" or "care". The most literal translation of conservatism into German would, in a non-political sense, be "Vorsicht", however, the most likely translation of "prudence" would be "Klugheit" (while "Klugheit" can also translate as "prudence", its more likely connotations would be "good sense", "intelligence"), "Vernunft" (reason), "Umsicht" ("circumspection") or "Besonnenheit" ("levelheadedness").

26. Garcia Lara and Mora (2002) distinguish between balance sheet conservatism and earnings conservatism. Balance sheet conservatism implies understatement of the book value of shareholders' equity; earnings conservatism is defined as a tendency to require a higher level of verification for the recognition of good news than for that of bad news (Garcia Lara and Mora, 2002). The traditional definitions of conservatism usually imply understatement of book values and earnings figures, however, Garcia Lara and Mora point out that earnings figures cannot be consistently undervalued, but rather that differences in earnings figures are temporary and will eventually reverse, i.e. "[d]ue to the accruals principle, the gains (losses) that we do not recognise now will be recognised later. Thus, in the long run, accounting earnings will reverse to economic earnings" (Garcia Lara and Mora, 2002, p. 2). It could however be argued that prudence implies the desire to acknowledge gains as late as possible, and losses as early as possible.

27. Evans and Nobes's (1996) translation of the German version ("Der Grundsatz der Vorsicht muss in jedem Fall beachtet werden"). The authors also suggest that the explicit mention of and emphasis on prudence probably originated in the UK's SSAP 2. However, although it was not mentioned as an accounting principle in the German law preceding the fourth directive, specific German accounting laws and non-codified regulation were in essence very prudent. I.e. it could be suggested that prudence was such an important principle in German accounting that it did not need to be explicitly mentioned as a principle in law, i.e. accounting rules and practices were essentially prudent (Evans and Nobes, 1996).

28. This trend has more recently been continued in the UK by the replacing of SSAP 2 by FRS 18, which no longer considers prudence a fundamental accounting concept. However, Garcia Lara and Mora (2002) note that the degree of balance sheet conservatism in the US has increased in the last 30 years. Further, earnings conservatism in the US has increased since the 1950s and seems linked to increasing litigation risk (ibid.). 
29. "Und wir halten ferner die Annahme für begründet, daß es nicht länger "true and fair view” hieße, sondern z.B. "generally accepted accounting principles", wenn solche auch in Großbritannien schon entwickelt worden wären".

30. "Die Norm "true and fair view" bedeutet somit "in Übereinstimmung mit den Grundsätzen ordnungsmäßiger Buchführung”"; and "Die Erwähnung der GoB in § 237 Abs. 2 HGBE bedeutet keine Einschränkung, sondern ist Tautologie". The reference to HGBE is to the draft German commercial code which implemented the 4th, 7th and 8th EU company law directives.

31. This does not suggest that overriding general clauses are completely alien to RG legal systems; however, in RG systems their role is limited to preventing the literal application of a specific rule against the spirit of the law and is de facto much more limited than that of TFV in UK law and accounting practice. For a more detailed discussion see Evans (2003).

\section{References}

Aisbitt, S. and Nobes, C. (2001), "The true and fair view requirement in recent national implementations", Accounting and Business Research, Vol. 31 No.2, pp. 83-90.

Albrecht, J. (1973), Linguistik und Übersetzung, Max Niemeyer, Tübingen.

Alexander, D. (1993), “A European true and fair view?”, European Accounting Review, Vol. 2 No. 1, pp. 59-80.

Alexander, D. (1996), “Truer and fairer. Uninvited comments on invited comments", European Accounting Review, Vol. 5 No. 3, pp. 483-93.

Alexander, D. (1999), "A benchmark for the adequacy of published financial statements", Accounting and Business Research, Vol. 29 No. 3, pp. 239-53.

Alexander, D. and Archer, S. (1999), "Metarules and flexibility in financial reporting: an Anglo-German conspiracy revealed", draft paper presented at the British Accounting Association International Accounting \& Finance Special Interest Group Conference, September, Napier University, Edinburgh. 
Archer, S. and McLeay, S. (1991), "Issues in transnational financial reporting: a linguistic analysis", Journal of Multi-Lingual and Multicultural Development, Vol. 12 No. 5, pp. 347-61.

Arden, M. (1993), “The true and fair requirement. Opinion”, in: Accounting Standards Board (Ed.) Accounting Standards 1998/9, "Foreword to accounting standards", Appendix, pp. 22-6, Accountancy Books/ICAEW, Central Milton Keynes.

Baetge, J. (1994), Bilanzen, 3rd revised edition, IDW-Verlag, Düsseldorf.

Bagranoff, N. A., Houghton, K. A. and Hronsky, J. (1994), “The structure of meaning in Accounting: a cross-cultural experiment", Behavioral Research in Accounting, Vol. 6 (Supplement), pp. 35-57.

Ballwieser, W. (1985), "Sind mit der neuen Generalklausel zur Rechnungslegung auch neue Prüfungspflichten verbunden?”, Betriebs-Berater, No. 16, pp. 1034-43.

Baskerville, R. F. (2003), "Hofstede never studied culture", Accounting, Organizations and Society, Vol. 28 No. 1, pp. 1-14.

Bassnett, S. (1998), “Translating across cultures", in Hunston, S. (Ed.) Language at Work, British Association for Applied Linguistics/Multilingual Matters Ltd, Clevedon/Philadelphia/Toronto/Sydney/Johannesburg, pp. 72-85.

Beisse, H. (1990), "Rechtsfragen der Gewinnung von GoB”, Betriebswirtschaftliche Forschung und Praxis, No. 6, pp. 499-514.

Beisse, H. (1993), “Gläubigerschutz - Grundprinzip des deutschen Bilanzrechts”, in Beisse, H., Lutter, M. and Närger, H. (Eds), Festschrift für Karl Beusch zum 68. Geburtstag, Verlag Walter de Gruyter, Berlin, pp. 77-97.

Belkaoui, A. (1978), "Linguistic relativity in accounting", Accounting, Organizations and Society, Vol. 3 No. 2, pp. 97-104. 
Belkaoui, A. (1980), “The interprofessional linguistic communication of accounting concepts: an experiment in sociolinguistics", Journal of Accounting Research, Vol. 18 No. 2, pp. 362-74.

Belkaoui, A. (1989), “Accounting and Language”, Journal of Accounting Literature, Vol. 8, pp. 281-92.

Belkaoui, A. (1990), Judgement in International Accounting, Quorum Books, New York/Westport/London.

Bertelsmann AG Financial Statements 1999.

Blake, J. and Amat, O. (1993), European Accounting, Pitman, London.

Bloom, R. and Naciri, M. A. (1989), “Accounting standard setting and culture: A comparative analysis of the United States, Canada, England, West Germany, Australia, New Zealand, Sweden, Japan, and Switzerland”, International Journal of Accounting, Vol. 24 No.1, pp. 70-97.

Busse von Colbe, W. (1984), "A true and fair view: A German perspective", in Gray, S. J. and Coenenberg, A. G. (Eds), EEC Accounting Harmonisation: Implementation and Impact of the Fourth Directive, Elsevier, Amsterdam.

Busse von Colbe, W. (1994), Lexicon des Rechnungswesens, 3rd ed., Oldenbourg Verlag, München/Wien.

Catford, J. C. (1965), A Linguistic Theory of Translation. An Essay in Applied Linguistics, Oxford University Press, London.

Chastney, J. G. (1975), True and Fair View - History, Meaning and the Impact of the 4th Directive, ICAEW Research Committee Occasional Paper No. 6.

Coenenberg, A.G. (1994), Jahresabschluß und Jahresabschlußanalyse, 15th revised edition, Verlag Moderne Industrie, Landsberg. 
Commission of the European Union, Accounting Advisory Forum (1995), Prudence and Matching, Directorate-General XV Internal Market and Financial Services, XV/7002/95 EN.

Crystal, D. (1987), The Cambridge Encyclopaedia of Language, Cambridge University Press, Cambridge.

d'Arcy, A. (2001), “Accounting classification and the international harmonisation debate - an empirical investigation", Accounting, Organizations and Society, Vol. 26, No. 4/5, pp. 327-49.

David, R. and Brierley, J. E. C. (1985), Major Legal Systems of the World Today, 4th ed., Stevens \& Sons, London.

Davidson, R. A. and Chrisman, H. H. (1993), "Interlinguistic comparison of international accounting standards: the case of uncertainty expressions", International Journal of Accounting, Vol. 28 No. 1, pp. 1-16.

Davidson, R. A. and Chrisman, H. H. (1994), “Translations of uncertainty expressions in Canadian accounting and auditing standards" Journal of International Accounting, Auditing and Taxation, No. 3 Vo. 2, pp. 187-203.

Doupnik, T. S. and Richter, M. (2002a), “Interpretation of uncertainty expressions: a cross-national study", Accounting, Organizations and Society, Vol. 28 No. 1, pp. $15-35$.

Doupnik, T. S. and Richter, M. (2002b), "Cross-cultural differences in the Interpretation of 'In-Context' Probability Expressions", Paper presented at the European Accounting Association Annual Congress, Copenhagen, April 2002. 
Evans, L. (2003), "The true and fair view and the "fair presentation" override of IAS 1", Accounting and Business Research, Vol. 3 No 4, forthcoming.

Evans, L. and Nobes, C. (1996), "Some mysteries relating to the prudence principle in the Fourth Directive and in German and British Law", European Accounting Review, Vol. 5 No. 2, pp. 361-373.

Evans, T. G., Taylor, M. E. Holzmann, O.J. (1994), International Accounting \& Reporting, 2nd edition, International Thomson Publishing, Cincinnati.

FEE (1997), Comparative Study on Conceptual Accounting Frameworks in Europe, FEE, Brussels.

Gallhofer, S. and Haslam, J. (1991), 'The aura of accounting in the context of a crisis: Germany and the first World War', Accounting, Organizations and Society, Vol. 16, No. 5/6, pp. 487-520.

Garcia Lara, J. M. and Mora, A. (2002), “Balance sheet vs. earnings conservatism in Europe", Paper presented at the European Accounting Association Annual Congress, Copenhagen, April 2002.

Gietzmann, M. and Quick, R. (1998), "Capping auditor liability: the German experience”, Accounting, Organizations and Society, Vol. 23 No.1, pp. 81-103.

Gray, S. J. (1980), “The impact of international differences from a security-analysis perspective: some European evidence", Journal of Accounting Research, Vol. 18 No. 1 , pp. 64-76.

Gray, S. J. (1988), "Towards a theory of cultural influence on the development of accounting systems internationally", Abacus, Vol. 24 No. 1, pp. 1-15.

Grossfeld, B. (1989), "Common roots of the European law of accounting", International Lawyer, Vol. 23 No. 4, pp. 865-72. 
Györi, G. (2000), "Semantic change as linguistic interpretation of the world", in Niemeier, S. and Direven, E. (Eds) Evidence for Linguistic Relativity, John Benjamins, Amsterdam/Philadelphia, pp. 71-89.

Haller, A. (1998), "Accounting in Germany", in: Walton, P., Haller, A. and Raffournier, B. (Eds), International Accounting, Thomson, London, pp. 78-107.

Haried, A. A. (1972), "The semantic dimension of financial statements", Journal of Accounting Research, Vol. 10 No. 2, pp. 376-91.

Haried, A. A. (1973), “The semantic dimension of financial statements", Journal of Accounting Research, Vol. 11 No. 1, pp. 117-145.

Haskins, M. E., Ferris, K. R. and Selling, T. I. (1996), International Financial Reporting and Analysis. A Contextual Emphasis, Irwin, Chicago.

Hewson, L., and Martin, J. (1991), Redefining Translation. The Variational Approach, Routledge, London.

Hintner, O. (1926), Das Treuhandwesen in der deutschen Volkswirtschaft, Habilitationsschrift, J. Schweitzer Verlag, München/ Berlin/Leipzig.

Houghton, K. A. (1987), "True and fair view: An empirical study of connotative meaning”, Accounting, Organizations and Society, Vol. 12 No. 2, pp. 143-52.

Jain, T. N. (1973), “Alternative methods of accounting and decision making: a psycholinguistic analysis”, Accounting Review, Vol. 48, January, pp. 95-104.

Joseph, J. E. (1995), “Indeterminancy, Translation and the Law”, in Morris, M. (Ed.) Translation and the Law, American Translators Association Scholarly Monograph Series Vol. VIII, John Benjamins Publishing, Amsterdam/Philadelphia, pp. 13-36. 
Joseph, J. E. (1998), "Why isn't translation impossible", in Hunston, S. (Ed.) Language at Work, British Association for Applied Linguistics/Multilingual Matters Ltd, Clevedon/Philadelphia/Toronto/Sydney/Johannesburg, pp. 86-97.

Kelly, L. G. (1994), “Translatability: Limits”, in Asher, R.E. and Simpson, J.M.Y. (Eds) The Encyclopedia of Language and Linguistics, Vol. 9, Pergamon Press, Oxford.

Kiralfy, A. K. R. (1968) "English law", in Debrett, J. D. M. (ed.) (1968) An Introduction to Legal Systems, Sweet and Maxwell, London, pp. 1-27.

Kosmala MacLullich, K. (2001), "Truth and Fairness in Accounting: A Case of Polish Transition Economy", CERT Discussion Papers, Heriot-Watt University, Edinburgh, October.

KPMG (1994), Significant Differences in Accounting Principles between the United Kingdom and Germany/Wesentliche Rechnungslegunsunterschiede zwischen Großbritannien und Deutschland, KPMG, Frankfurt am Main/London.

Leffson, U. (1979), “Zur Bedeutung des $§ 149$ AktG und Art. 2 Abs.3 der 4. EGRichtlinie", Zeitschrift für betriebswirtschaftliche Forschung und Praxis, Vol. 31, pp. 213-6.

Leffson, U. (1987a), “Ausformulierte und nicht ausformulierte gesetzliche Vorschriften im Bilanzrecht des HGB”, Die Betriebswirtschaft, Vol. 47, pp. 3-7. Leffson, U. (1987b), Die Grundsätze Ordnungsmäßiger Buchführung, 7th revised and extended edition, IDW-Verlag, Düsseldorf.

Lowe, T., Gallhofer, S. and Haslam, J. (1991), “Theorizing accounting regulation in a global context: Insights from a study of accounting in the Federal Republic of Germany", Advances in Public Interest Accounting, Vol. 4, pp. 143-77. 
Lucy, J. A. (1992), Language Diversity and Thought: A Reformulation of the Linguistic Relativity Hypothesis, Cambridge University Press, Cambridge.

Lucy, J. A. and Shweder, R. A. (1979), "Whorf and his critics: Linguistic and nonlinguistic influences on colour memory. American Anthropologist, 81, pp. 581-615.

Macharzina, K. (1981), "Financial Reporting in West Germany", in Nobes, C. and Parker, R. (Eds).

Maley, Y. (1994), “The language of the law”, in Gibbons, J. (Ed.), Language and the Law, Longman, London/New York.

Matthews, D., Anderson, M. and Edwards, J.R. (1998). The Priesthood of Industry. The Rise of the Professional Accountant in British Management. Oxford University Press, Oxford.

McGee, A. (1992), “The "true and fair view" debate: a study in the legal regulation of accounting", in Freedman, J. and Power, M. (Eds) Law and Accountancy Conflict and Co-operation in the 1990s', London, Paul Chapman Publishing, pp. 106-20.

Nida, E. (1996), "Translation: Possible and Impossible", in Rose, M.G. (Ed.) Translation Horizons. Beyond the Boundaries of Translation Spectrum, Translation Perspectives IX, State University of New York, Binghamton, pp. 723.

Niehus, R. J. (1979), “'True and Fair View” - in Zukunft auch ein Bestandteil der deutschen Rechnungslegung?", Der Betrieb, Vol. 32 No. 5, pp. 221-5.

Nobes, C. (1993), “The True and Fair View Requirement: Impact on and of the Fourth Directive", Accounting and Business Research, Vol. 24 No.93, pp. 35-48. 
Nobes, C. (2002a), "Causes of international differences", in Nobes, C. and Parker, R. (Eds)., pp. 17-33.

Nobes, C. (2002b), "Financial reporting in the United States", in Nobes, C. and Parker, R. (Eds)., pp. 165-94.

Nobes, C. and Parker, R. (Eds) (1981/1995/02), Comparative International Accounting, 1st, 4th and 7th edition, Prentice Hall, London.

Oliver, B. L. (1974), "The semantic differential: a device for measuring the interprofessional communication of selected accounting concepts", Journal of Accounting Research, Vol. 12 No. 2, pp. 299-316.

Ordelheide, D. (1990), "Soft-transformations of accounting rules of the 4th Directive in Germany", Les Cahiers Internationaux de la Comptabilité, Vol. 3, pp. 1-15.

Ordelheide, D. (1993), "True and fair view. A European and a German perspective", European Accounting Review, Vol. 2 No. 1, pp. 81-90.

Ordelheide, D. (1999), "Germany”, in McLeay, S. (Ed.) Accounting Regulation in Europe, Macmillan, Houndmills.

Ordelheide, D. and Pfaff, D. (1994), European Financial Reporting. Germany, Routledge, London.

Parker R. H. (2001), “European languages of account”, European Accounting Review, Vol. 10 No. 1, pp. 133-147.

Parker, R. H. (1989), “Importing and exporting accounting: the British experience”, in Hopwood, A. (Ed.) International Pressures for Accounting Change, Prentice Hall/ICAEW, Hemel Hempstead, pp. 7-29.

Parker, R. H. (1994), "Finding English words to talk about accounting concepts", Accounting, Auditing \& Accountability Journal, Vol. 7 No. 2, pp. 70-85. 
Parker, R. H. (2000), "English and other languages of account”, English Today, Vol. 16 No. 2, pp. 43-56.

Parker, R. H. and Nobes, C. W. (Eds) (1994) An International View of True and Fair Reporting. London/New York: Routledge.

Peltzer, M., Doyle, J. and Allen, M.-T. (1995), German Commercial Code. German English Text with an Introduction in English, 3rd revised edition, Otto Schmidt, Köln.

Popper, K. R. (1994), The Myth of the Framework. In Defence of Science and Rationality, Routledge, London.

Riahi-Belkaoui, A. and Picur, R. R. (1991), "Cultural determinism and the perception of accounting concepts", International Journal of Accounting, Vol. 26 No. 2, pp. 118-130.

Rutherford, B. A. (1983), "Spoilt beauty: the true and fair view doctrine in translation”, AUTA (Association of University Teachers in Accounting) Review, Spring, pp. 33-6.

Rutherford, B. A. (1985), "The true and fair view doctrine: a search for explication", Journal of Business Finance \& Accounting, Vol. 12 No. 4, pp. 484-94.

Salter, S. B. and Doupnik, T. S. (1992), “The relationship between legal systems and accounting practices: a classification exercise", in Most, K. (ed.) Advances in International Accounting, Volume 5, Jai Press, London/Greenwich Connecticut, pp. 3-22.

Sampson, G. (1997), Educating Eve: The "Language Instinct" Debate, Cassell, London. 
Sapir, E. (1929/1949), “The status of linguistics as a science”, in Mandelbaum, D.G. (1949) (Ed.), Selected Writings of Edward Sapir in Language, Culture and Personality, University of California Press, Berkeley/Los Angeles.

Saussure, F. (1915/66), Course in General Linguistics, The Philosophical Library, New York.

Schildbach, T. (1979) "Die Auswirkungen der Generalklausel des Artikel 2 der 4. EGRichtlinie auf die Rechnungslegung der Aktiengesellschaften. Eine Analyse vor dem Hintergrund der Einzelvorschriften der 4. EG-Richtlinie", Die Wirtschaftsprüfung, 11, pp. 277-86.

Schildbach, T. (2000), US GAAP: Amerikanische Rechnungslegung und ihre Grundlagen, Verlag Vahlen, München.

Scholtissek, W. (1984), "Die künftige Generalnorm "True and fair view", im deutschen Handelsrecht”, Die Information über Steuer und Wirtschaft, No. 3-4, pp. 66-8.

Scholtissek, W. (1986), "True and fair view im Vereinigten Königreich und in der Bundesrepublik Deutschland", Recht der Internationalen Wirtschaft, Vol. 32 No. 12, pp. 966-70.

Schön, W. (1997), “Entwicklung und Perspektiven des Handelsbilanzrechts: vom ADHGB zum IASC", Zeitschrift für das gesamte Handelsrecht und Wirtschaftsrecht, No. 161, pp. 133-159.

Smith, S. (1995), "Culture clash: Anglo-American case law and German civil law in translation", in Morris, M. (Ed.) Translation and the Law, American Translators Association Scholarly Monograph Series Vol. VIII, John Benjamins Publishing, Amsterdam/Philadelphia, pp. 179-97. 
Thomas, J. A. C. (1968), "Roman law", in Debrett, J. D. M. (ed.) (1968) An Introduction to Legal Systems, Sweet and Maxwell, London, pp. 1-27.

Thomas, S. (1998), "Translation as intercultural conflict", in Hunston, S. (Ed.) Language at Work, British Association for Applied Linguistics/Multilingual Matters Ltd, Clevedon/Philadelphia/Toronto/Sydney/Johannesburg, pp. 98-108.

Van Hulle, K. (1997), "The true and fair view override in the European Accounting Directives", European Accounting Review, Vol. 6 No. 4, pp. 711-20.

von Wysocki, K. (1983), "Research into the processes of accounting standard setting in the Federal Republic of Germany“, in Bromwich, M. and Hopwood, A.G. (Eds) Accounting Standards Setting: An International Perspective, Pitman, London.

Walton, P. (1991), The True and Fair View: A Shifting Concept, ACCA Occasional Paper No. 7, The Chartered Association of Certified Accountants.

Werner, O. (1994), "Sapir-Whorf Hypothesis", in Asher, R.E. and Simpson, J.M.Y. (Eds) The Encyclopedia of Language and Linguistics, Vol. 7, Pergamon Press, Oxford.

Wierzbicka, A. (1992), Semantics, Culture and Cognition: Universal Human Concepts in Culture-Specific Configurations, Oxford University Press, New York and Oxford.

Working Group on External Financial Reporting of the Schmalenbach-GesellschaftDeutsche Gesellschaft für Betriebswirtschaft (1995), Accounting Horizons, Vol. 9 No. 3, pp. 92-9.

Wylie, J. K. (1948), "Roman law as an element in European culture", South African Law Journal, Vol. 65, pp. 4-13; 201-12; 349-361 (summary of Koschaker, P. (1947), Europa und das Römische Recht, Biederstein Verlag, Munich. 
Zeff, S. (1990/1994), “The English-language equivalent of Geeft een Getrouw Beeld”, in Parker, R. H. and Nobes, C. W. (Eds), pp. 131-3. 